\title{
From Research on the Musical "Trans-avant-garde": A Contribution to the Discussion on the Terminology Concerning the Historiography of 20th Century Polish Music
}

\author{
Monika Karwaszewska \\ The Stanisław Moniuszko Music Academy in Gdańsk \\ mon-kar@wp.pl
}

\begin{abstract}
The research article discusses the concept of "the trans-avant-garde" (a term coined by the Italian art critic Achille Bonito Oliva to describe certain phenomena in visual arts, especially painting, which have appeared since the end of the 1970s) and attempts to adapt it for a discussion of twentieth century Polish music. The trans-avant-garde (Italian la transavanguardia) is an Italian form of expressionism in art (neo-expressionism), originating as a rejection of modernism, formalism, innovation, originality, and stylistic coherence, which began to treat tradition in a new way, extensively referring to $16^{\text {th }}$ century mannerisms, ambiguity, stylistic pluralism and polysemy.

While, on the one hand, trans-avant-garde artists are fully aware of the crisis of the avantgarde experiment, on the other, they aim to create content-packed works of deeply expressive and romantic character. The trans-avant-garde is widely considered to be an early stage of postmodernism, or simply its synonym. There is a difference, though, between the trans-avant-garde and the postmodern. Oliva speaks of a journey from America to Europe and back. My article discusses these differences, systematizes the most important stylistic aspects and aesthetic ideas, and applies these observations to the study of musica discipline Oliva did not take into consideration.

A key issue in the description of the trans-avant-garde in Polish music is analysis of the trends that precede it, are synchronous with it, and follow it in history. It is also important to trace borrowings and differences along this time axis. In order to offer an insight of this kind, I first present the different concepts of "modernity" and "postmodernity" that have appeared in music (and art) of the twentieth century, and I then juxtapose those with the Italian original idea of la transavanguardia.
\end{abstract}

Keywords: Italian transavantgarde; neo-expressionism in music; Polish music of the $20^{\text {th }}$ and $21^{\text {st }}$ century; postmodernism. 
Art comes full circle, trends disappear and return in a new character. One needs to look at them critically and translate them into the present. ${ }^{1}$

Achille Bonito Oliva

Trans-avant-garde is a notion little known in contemporary composer communities and completely disregarded in Polish musicological writing. The key issues in the description of trans-avant-garde in Polish music concern the reconstruction of principles of music trends that both preceded it and co-occurred with it as well as establishing the main features borrowed from those trends and determining the divergent ideas. The reconstruction will consist of gathering the various concepts of the phenomena of "modernity" and widely understood "postmodernity" that are present in art (mainly the music) of the previous century and these will be referred to the Italian original promoted in painting at the end of the 1970s and in the 1980s. The status of this trend in music is still unclear and raises numerous doubts, which is why detailed interdisciplinary research is required. This paper will make it possible to systematize the terminology used by Polish musicologists, music theoreticians and aestheticians to refer to the trends and attitudes in the musical art of the $20^{\text {th }}$ century that are described as modernistic or avant-garde. On the one hand, the paper will also make it possible to determine their time spans and basic paradigms, and on the other both place trans-avant-garde within those time spans and describe it Only then will it be possible to create a model and arbitrary pattern of a music piece that displays the features of the Italian trans-avant-garde.

\section{Terminology and periodization dilemmas}

Periodization of the $20^{\text {th }}$ century music, both European and Polish, and establishing unequivocal key points in the process of transformations of the history of musical culture are still dubious and subject to different interpretations. However, two "certain" caesuras are determined by the two world wars: the end of the $1^{\text {st }}$ World War coincided with the end of the first phase of modernism, while the end of the $2^{\text {nd }}$ World War brought about the birth of avant-garde. The two terms, i.e. modernism and avant-garde, as well as terms derived from them, have been used by the authors of works referring to music to describe various phenomena observed in composers' works of the $20^{\text {th }}$ century. In Polish musicological texts, they are most commonly used to describe phenomena related to artistic trend, style, aesthetic attitude and social-historical formation. Hence, it seems to be of key importance to explain the meanings of basic terms, i.e. modernism and avant-garde, as they are used in music-related literature. This begins with an analysis of how they function in humanities.

\footnotetext{
${ }^{1}$ Oliva 2012. This passage rendered into English is my own translation, as are all the subsequent passages unless indicated otherwise.
} 
The term modernism comes from French modernisme (from moderne-modern). The first meaning of the term modernism refers to all avant-garde trends in the literature and art of the 1880-1910 period. In music, the beginning of modernism is placed by Dahlhaus in the year 1890, which was the year when Gustav Mahler's I Symphony and Richard Strauss' Don Juan were created, while the period is indicated to have ended in approximately 1910 , when Schönberg's atonal experiments and Stravinsky's rhythmical innovations appeared (Dahlhaus 1982: 62). According to Ryszard Nycz, a Polish literary scholar, modernism "is characterised as a vast art-worldview formation, extending from its beginnings at the end of the $19^{\text {th }}$ century to its exhaustion in the 1960 s, and shown in a close relationship to the processes of social, cultural and civilizational modernisation" (Nycz 2013: 9-10). Therefore, this is not a matter of drawing the boundaries between literary trends or boundaries determined by important historical events or social-political coups. In the development of modern literature, Nycz distinguishes (2013: 88) between two basic traditions: classicalmodern and avant-garde modern, whose boundaries are determined solely by linguistic phenomena. The concept of modernism in western literary studies brings to focus the root of its meaning: modernity. (Contrary to the Polish tradition, where the adjective "modernistyczny" is associated with the archaic.)

The term avant-garde derives from military language (Fr. avand-garde refers to vanguard, the troops ahead of the main forces). In the $19^{\text {th }}$ century, the concept was adopted by art criticism to convey the meaning of dynamism and radicalism of artistic attitude. In the $20^{\text {th }}$ century, artistic attitude associated with the idea of progress was referred to as "new art" or "modernistic." In German and English criticism, the term avant-garde was adopted no sooner than the end of the 1950s, at which time the artistic movements from the beginning of the century were labelled as the "First," "Great" or "Old" Avant-garde, while the post $2^{\text {nd }}$ World War movements were referred to as "Neo-" or "Second" Avant-garde. In the 1960s, the phenomena of avant-garde and neo-avantgarde became of interest to one of the outstanding theoreticians and experts on avant-garde art, Stefan Morawski. He considered the moment of emergence of avant-garde art, which he described as modern art, to have been the time when the symptoms of the so-called crisis in art appeared (Morawski 2007: XXXVII). He contrasted the avant-garde of the first half of the $20^{\text {th }}$ century, which he identified with the notion of the first avant-garde that emphasised innovation in art, with the neo-avantgarde of the second half of the century, which he also identified with the second avant-garde, and, initially, even with postmodernism. Morawski applied these notions to the plastic arts, literature and music. According to him, the avant-garde formation consists in four models of creation (2007: XLV):

- avant-garde, autotelic (authors of new plastic and poetic values, first and second film avant-garde);

- $\quad$ involved (stressing the artist as a tribune, emphasising political issues);

- heroic-pessimistic (expressionistic artist, author attacked by an authoritarian system);

- $\quad$ utilitarian-artistic (authors stressing simple and clear constructions). 
The neo-avantgarde formation's identity, also called postmodernist, was due to the significant technological and scientific development. In addition, in this case, four basic models are distinguished by Morawski (2007: XLVI-LI):

- technological (installations, computer and electronic art, photomedia);

- popster-hyperrealistic (author referring to the imagery which is an element of mass culture - posters, commercials, TV);

- ludic-aleatoric (actionistic) (happenings, performances, street theatres, aleatoricism, instrumental theatre);

- $\quad$ process art (meta-artistic art) (meta-art, concrete poetry, graphic music).

Neo-avantgarde, according to Stefan Morawski, "undermines the concept of art and instead advocates practising anti-art in which the previous aesthetic categories, i.e. form, virtuosity, expression, mimesis, talent and genius, do not play any role" (2007a: 212). As noted by Morawski, Neo-avantgarde choices were made outside of art, which by some scholars was seen as the end of artistic avant-garde in its strict sense. Morawski mentions also the fact that a special role was attributed to arrangement and idea, while good structure of the form of a work of art was neglected.

The semantic range of terms differs from text to text. Previously, numerous scholars have found it difficult to situate in relation to one another such concepts as modernism and postmodernism, avant-garde, neo-avantgarde and trans-avant-garde, modernity and postmodernity and still there is no constant formula to be used to describe "musical avantgarde" in its strict sense. As rightly noted by Maciej Gołąb, a certain degree of terminological incoherence

may result from a relatively rarely used today by the historians of the $20^{\text {th }}$ century music notion of modernism, even though it originates from the German Musikgeschichtsschreibung (the concept of musikalische Moderne, which refers to the period at the turn of the $19^{\text {th }}$ and $20^{\text {th }}$ centuries). The scholars prefer the concept of avant-garde that is rooted in texts ... and the emerging — as a result of [its] crisis - postmodernism, as opposed to the historical or contemporary modernism. (Gołąb 2011: 34-35)

It should be noted that musicologists and music theoreticians tend to bracket the activities of last century composers as belonging to particular artistic trends/currents or generations of composers.

Due to the dominating trends and currents in art, two basic notions referring to composers' attitudes appear in works by Polish musicologists and aestheticians: modernist and avantgarde. These notions, in turn, make it possible to distinguish the next ones, directly related to the historical and aesthetic development of these formations:

- $\quad$ modernism $\rightarrow$ postmodernism or, using specifically Polish terminology, moderna, $\rightarrow$ moderna I $\rightarrow$ moderna II, $\rightarrow$ postmoderna;

- $\quad$ avant-garde $\rightarrow$ neo-avantgarde $\rightarrow$ trans-avant-garde or, using a different terminology) avant-garde I $\rightarrow$ avant-garde II. 
Thus, a hundred year period of development of art yields a multiplicity of kaleidoscopic configurations of the widely understood "avant-garde."

For example, a Polish musicologist, Maciej Gołąb, uses in his works the term moderna, translated into English as modernism. He understands it as

a certain hidden "invisible" social-historical formation. He does not place it in opposition to either avant-garde or postmodernism ... Musical modernism, understood as a socialhistorical concept, unites those composers ... who creatively marked their presence in the history of $20^{\text {th }}$ century music; $\ldots$ also unites those who rank the value of "difference" higher than the idea of newness and progress. It is not then [according to Gołąb] novelty in the musical culture, but cultural change in general that constitutes the criterion for the presence of modernism, regardless of the degree of reference to the past or the degree of mastering compositional skills. (Gołąb 2011: 35)

In musical art, a model of so-called "modernism fluctuation" is observed, consisting of 20 or 25 year cycles that show the varying intensity of strengthening or hindering the tendencies of avant-garde's presence in the artistic culture of the $20^{\text {th }}$ century (Gołąb 2003: 170). Gołąb determined five artistic formations that constitute this model (2003: 171):

- modernism (formation of the neo-romantic composers active in the years 1890-1910);

- modernism I (a group of expressionist composers active in the years 1910-1935);

- modernism outlawed (composers active in the totalitarian systems in the years 1935-1956) resulting from political, not artistic events [enslaved modernism],

- modernism II (composers in the years 1956-1975 focused on innovative concepts of structuring musical form);

- $\quad$ postmodernism (approximately in the 70s, a crisis affects the avant-garde ideas and "liberated modernism," i.e. postmodernism, emerges).

The period before 1935 is the first period of avant-garde (called here modernism I), while the year 1950 approximately marks the beginning of the second avant-garde (called here modernism II), identified with neo-avantgarde.

On the other hand, Zbigniew Skowron introduces the term "musical avant-garde" to refer to the new phenomena, trends and composers' attitudes in the music of the 1940s and $50 \mathrm{~s}$, characterised by innovative treatment of sound matter and opposition to tradition, described by scholars in musicological literature as "new music," "contemporary music," "today's music," "modern music," and "avant-garde music" (Skowron 1989: 11). The avant-garde phenomena in the music of the $20^{\text {th }}$ century occurred twice, which makes it possible to distinguish two avant-garde phases and formations:

- the first avant-garde (historical) up to the $2^{\text {nd }}$ World War (futurism, French avantgarde, the Vienna School of the $20^{\text {th }}$ century, American avant-garde), Polish avant-garde of the period between the wars;

- the second avant-garde (post-war): total serialism, concrete and electronic music, new structural concepts, aleatoric music, computer music, structural and sonorist concepts in Poland after the year 1956, unism, happening, multimedia. 
Alicja Jarzębska adopted the term musical modernism from the book Modern Times, edited by Robert Morgan. She uses the term modernism to refer to the period from the end of the $19^{\text {th }}$ century to the end of the $1970 \mathrm{~s}$. She claims that the new "modernist" meaning of the term departs from the centuries-old tradition of order associated with the idea of beauty. The term "music" in the modernist period means emotional and intellectual disorder, expression and chaos. Then comes the time referred to as post-modernist, linked with new phenomena in modern musical culture. She also employs the term musical avantgarde, functioning in the post-war years, whose

aim was to liberate the composer from the old conventions and rules of composition and also to achieve innovative sound effects as well as anti-narrative flow of acoustic events ... to eliminate any quasi-melodic and euphonic sound combinations and the effect of repetitiveness or similarity as well as the effect of tension gradation and culmination. (Jarzębska 2004: 2018)

Jarzębska applies the terms postmodernist and postmodern music to works created since the 1970s.

Jadwiga Paja-Stach understands modernism and postmodernism as epochs in the history of culture and presents the differences in artists' attitudes to the artistic achievements of the past (2007: 57):

- modernism (app. 1890-app. 1970): innovative attitude, which accepts tradition; avant-garde attitude, which rejects tradition;

- postmodernism (app. 1970-): buff attitude - ludic treatment of traditional elements, seria attitude - “attentive" assimilation of traditional elements.

Małgorzata Woźna-Stankiewicz, when evaluating the musical art of the $20^{\text {th }}$ and $21^{\text {st }}$ centuries with reference to various suggestions for interpreting the postmodernist phenomena, distinguishes three artistic attitudes of composers as regards their stance on tradition (2007: 81):

- modernist (a complete rejection of tradition: dodecaphony, serialism, avantgarde I and II, novelty, experiment, sonorism, aleatoricism, happening);

- anti-modernist (reinterpretation of the past and excessive emphasis on the authority of tradition: neoclassicism, neostyle, neotonality);

- postmodernist (equally justified and selective usage of the whole, including the latest, heritage: pluralism, eclectism, freedom, relativism, post-avantgarde, intertextual techniques, minimalism, repetitiveness, New Age, a return to roots).

Leszek Polony, a Polish aesthetician and music theoretician, distinguished three formations in the history of art and culture of the $20^{\text {th }}$ century: avant-garde; neo-avantgarde, the so called "anti-art avant-garde" that emerged around the mid-1950s and radically questioned all the basic aesthetic categories (1991: 313); and the third formation, which was critical towards the "anti-art avant-garde" and entered the artistic stage in the 1970s (1991: 342).

Musicologists, however, rarely use the term trans-avant-garde to describe the phenomena of postmodern art in which 'the ideology of 'progress' began to lose its momentum in the mid-1970s and was replaced by the categories: 'postmodernism,' 'postmodernity,' and 
'New Age'” (Gołąb 2011: 34). Małgorzata Woźna-Stankiewicz, in turn, suggests the term post-avantgarde within the postmodern attitude of composers. The term trans-avant-garde is used in her work Wariacje na postmodernizm by aesthetician and philosopher Krystyna Wilkoszewska. While describing postmodernism in philosophy and art, including literature, architecture, plastic arts (painting and sculpture) and film, she suggests abandoning the term postmodernism in the field of plastic arts in favour of a sequence of concepts: avant-garde - neo-avantgarde - trans-avant-garde, in which the last one, as a transgression of avant-garde, is meant to be a synonym of postmodernism (2008: 192). Grzegorz Dziamski, in his description of avant-garde art and the art created since the 1970s, introduced the term trans-avantgarde, understanding it as an art

transgressing nothing more or less than avant-garde itself ... and which attacked the key concepts of the avant-garde discourse - novelty, originality, exceptionality, authenticity, self-referentiality - rehabilitating those categories that avant-garde, seemingly forever, had sent to the wastebasket of history: manual ability, painting tradition, communicativeness, artistic aura, figurativeness, narrativeness, subjectivity, expression of desires and emotions, classic forms, regional motifs ... Trans-avantgarde was not a return to the past, but, as it would soon turn out, a reach for new sources of inspiration in order to better rise to the challenges of the future. (Dziamski 1995: 7-8)

The art of that period is described by Dziamski as "postmodern art, regarded as the art after the end of art; as art liberated from the modern metanarratives as well as art open to the multimedia reality of the present day" (Dziamski 2002:19).

The outstanding expert on postmodernism, Jean-Francois Lyotard, when discussing transavantgarde and neo-expressionism in the publication Art and Philosophy, considers these forms of a painter's expression to be "a passing moment of forgetting about everything that people had tried to achieve for the whole century, a loss of all those meanings which had seemed fundamental to painting" (Virilio 1991: 70; Qtd. in: Dziamski 1995: 9).

Anna Rutkowska, in her essay on postmodernism, writes that

it emerged in the seventies, in the culture of the so-called highly developed civilisation of the West ... it is a sum of phenomena, which is why it is better to refer to it as postmodernity or postmodern reality, so that the name does not suggest any analogies to trends and styles in art or composing techniques. This postmodernity is a multifaceted mixture of elements of the so-called high culture with elements of mass culture. (Rutkowska 2005: 284)

In order to describe the art of the end of the $20^{\text {th }}$ century, Krzysztof Baculewski, a Polish composer, in the monograph Współczesność 1975-2000. Historia muzyki polskiej pod redakcja Stefana Sutkowskiego, introduces the term trans-avant-garde as a phenomenon the same as postmodernism, new expression, postmoderna, postmodernisticality, postmodernity, or post-art (2012: 155). Baculewski emphasises that "one of the tendencies within this trend was reaching into various trends and styles, [and] trans-avant-garde poetics became one of the manifestations of the postmodern, non-uniform and sometimes contradictory world" (2012: 171-172). 
However, Krzysztof Szwajgier, a music theoretician, presents in his text Sonoryzm wobec wspótczesności an original vision of changes occurring in modern Polish music after the social transformation that took place in 1968. The author distinguished "three trends that developed in parallel and constituted the paradigm of musical postmodernism:

- $\quad$ essentialism (minimalism, reductionism, naturalism);

- $\quad$ traditionalism (postmoderna, new romanticism, polystylistics);

- trans-avant-gard (late modernism, neo-avantgarde, neomodernism);

suggesting in brackets also alternative terms which are postulatory in character" (2014: 26).

Trans-avant-garde is understood by Szwajgier as one of the paradigms of modernism, exemplified, among others, by trends such as intermediality and post-sonorism, within which the works of Tadeusz Wielecki (the theoretical category of a musical gesture) and Lidia Zielińska's musical archipelagos may be placed (2014: 25). A practical implementation of the idea of musical gesture is three compositions by Wielecki entitled Studium gestu. These were written in succession for the clarinet, piano and cello (1995), piano (1997) and clarinet, trombone, piano, cello and double bass (2000).

It needs to be stressed, however, that the term trans-avant-garde originates from Italy (it. la transavanguardia). It is a trend in art suggested by Italian modern art critic and historian Achille Bonito Oliva to refer to the artistic phenomena (mainly in painting) observed almost simultaneously in a number of countries since the end of the 1970s (Italy, la transavanguardia or Arte cifra; France, Nouveaux fauves or La Figuration libre; the United States, New Wave; Scandinavia and Germany, Neue Wilde; Poland, Nowa ekspresja). The critic explains that while determining this phenomenon, he reached for expressionism which was absent from Italy in its clear form. It constitutes the Italian variety of expressionist tendencies in art (neo-expressionism) that stems from opposition against modernism, formalism, innovativeness, originality and stylistic coherence, and which takes advantage of tradition in a new way at the same time referring to the $16^{\text {th }}$ century mannerisms of fuzziness, stylistic pluralism and polysemy. Trans-avant-garde, according to Oliva, makes use of prior works in the form of citation presented in expressionist stylistics. The critic sees its origin in the activities of a group of Italian artists that adopted the name "Arte cifra": in the 1970s, Enzo Cucchi, Sandro Chia, Francesco Clemente, Mimmo Paladino and Francesco De Maria combined figurativeness with abstraction in their expressionist works. Oliva does not perceive this trend as an anti-avant-garde tendency, but rather as progress in the linear order of the history of art. A trans-avant-garde artist is an artist who is, on the one hand, fully aware of the crisis of avant-garde and the associated progress or experiment, but who, on the other hand, is oriented towards the freedom of creating "content" works, characterised by deep expression and romanticism.

Trans-avant-garde is considered the initial phase of postmodernism and these two are often treated as identical. However, there is a difference between them, which Oliva compares to a trip from America to Europe and the other way round. Oliva holds the opinion that 
trans-avant-garde liberated artists ... liberated authors from the ideology of linguistic Darwinism, the concept of linear development of art ... it brought back the romantic aspect to art, gave it an anthropological identity and a territory, which entered into interaction with various means of communication. (Oliva 2012)

The premiere of the term la transavanguardia took place in 1979 in the magazine "Flash Art," in which Oliva published the essay entitled "The Italian Trans-Avantgarde" (1979: 17-20). A year later, the first book concerning the Italian trans-avant-garde appeared in two language versions: The Italian Trans-avantgarde, La Transavanguardia Italiana (Oliva 1980) and a monograph on world trans-avant-garde, Trans-avantgarde international (Oliva 1982), both of which brought success to the author in this field.

\section{Prologue to adaptation of the notion of trans-avant-garde to the historiography of $20^{\text {th }}$ century Polish music}

The basis for formulating the author's concept of musical trans-avant-garde, besides the trend's assumptions formed by Oliva in the field of painting, will be the terminology suggested by Krzysztof Szwajgier, Leszek Polony, Krystyna Wilkoszewska and Grzegorz Dziamski. Lack of unequivocal terminology severely hinders conclusive statements and causes the postulatory character of the suggested terms for describing the phenomena present in the Polish music of the $20^{\text {th }}$ century.

The division of the Polish music of the previous century, which is presented below, into four main phases and the corresponding artistic movements has been made on the basis of the following: the different treatment of novelty in modern art (opposition between avantgarde and neo-avant-garde); the terminology described above; the political-social transformations and the associated innovative artistic attitudes.

- $\quad$ from 1918 to 1939 (period between the wars): avant-garde (Polish expressionism);

- $\quad$ from 1939 to 1956 (foreign occupation period, totalitarian systems): anti-avantgarde (Polish neoclassicism, folklorism, socialist realism);

- $\quad$ from 1956 to 1968 (October thaw): neo-avantgarde or new avant-garde (dodecaphony, serialism, sonorism, punctualism, post-serialism, aleatoric music, conceptualism, electronic and concrete music, electroacoustic music, instrumental theatre, happening, graphic music);

- $\quad$ since 1968 (March events): post-avantgarde or avant-garde after avant-garde (essentialism [minimalism/unism, reductionism, spectralism], traditionalism [stylistic pluralism, eclectism], trans-avant-garde [neo-romanticism, neo-expressionism, intermediality]).

For the period beginning in 1968, when other scholars see the rise of postmodernist tendencies in art that are associated with "the state of soul and mind" rather than with a historical period, the notion of postavantgarde may be proposed, which is understood as the presence of "avant-garde after avant-garde" or new modernism. It is worth adding that 
when postmodernism started to be intensively proclaimed in the $1970 \mathrm{~s}$, there were manifestations in the West of a group of French spectralists whose works did not have much to do with postmodernism since they constituted instead a continuation of avant-garde. However, within widely understood postmodernism, new stylistic trends were formed which definitely broke with the idea of novelty in art (associated with avant-garde) as well as trends which still draw from it, resulting in works of a new category.

Following the particularization of postmodernism suggested by Krzysztof Szwajgier, postavantgarde has been divided into three discrete stylistic trends that have been differentiated not on the basis of succession in time, but due to the composers' attitudes that were dominant in them (essentialism, traditionalism, transavantgarde). This type of division and suggested trends also apply to modern music. Trans-avant-garde may be a similar case to postmodernism or postmoderna, which were transferred into the field of music from the area of literary studies, philosophical studies, architecture and painting.

The author understands trans-avant-garde as a stylistic trend that is not a direct continuation of avant-garde, but rather one that immediately follows the latter. Trans-avant-garde, as this specific continuation of avant-garde, allows acceptance of everything that was rejected by anti-art and lets it be shown in a completely new light, with the focus on a turn towards neo-romanticism, new expression, a return to emphasising the content of the work, to the function of symbol in music, usage of traditional formal structures and of the new media.

The phenomenon of trans-avant-garde is constituted by three basic trends and aesthetic categories: neo-expressionism, associated with new expression; neo-romanticism or rather neo-neo-romanticism since neo-romanticism as a trend in Polish music already existed; and a broadly understood intermediality, which is "the consequence of a more and more strongly present concept of transgressing the artistic boundaries by means of experimental examination of their potential for hybridisation" (Wasilewska-Chmura 2011: 132), in which a fundamental role is played by expansion and development of new media. In the author's opinion, a musical work that meets the criteria of musical trans-avant-garde should be a synthesis of the codes of tradition and modernity, with the following in particular:

- $\quad$ created after the year 1975;

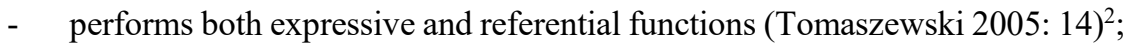

- $\quad$ is characterised by profound and extreme emotionalism;

- $\quad$ exhibits the features of neo-romanticism;

- has fluent, unfragmented musical narration;

- $\quad$ has uncomplicated formal structure;

- $\quad$ optionally contains an intensely expressive verbal text or is based on literary content;

- combines a number of techniques and composing styles derived from the past and presents them in a modern version;

\footnotetext{
${ }^{2}$ Main functions of a music piece in artistic space according to Mieczysław Tomaszewski.
} 
- $\quad$ enables its perception as an artistic intermedial form which is an integration of various semiotic systems as well as audio-visual techniques and technologies, including digital and electronic media;

- $\quad$ allows for its functioning as inclusive music, "absorbing, receiving ... a foreign fragment in the way which is tuned with the whole ... manifested in quotations, allusions and reminiscences" (Tomaszewski 2005: 29). ${ }^{3}$

The first traces of these assumptions are observed in the works of the composers of Name of formation "Stalowa Wola" 1951 generation represented by Andrzej Krzanowski, Aleksander Lasoń and Eugeniusz Knapik, whose output turned out to be ground-breaking and constituted a new trend. Further, the features may be observed in the works of composers born in the 1920s and 1930s, including Krzysztof Penderecki, Henryk Mikołaj Górecki, Włodzimierz Kotoński, Tadeusz Baird, Zbigniew Bujarski, Zygmunt Krauze, Andrzej Dobrowolski, and Bogusław Schaeffer, as well as in the output of composers younger than these such as Krzysztof Knittel or Paweł Mykietyn, who present the effects of their work at the International Modern Music Festival "Warsaw Autumn."

Works which may be treated as signals of the forthcoming trend are the compositions on religious themes by Krzysztof Penderecki created in 1974, i.e. The Awakening of Jacob for orchestra and Magnificat for solo bass, vocal ensemble, two mixed choirs, boys' voices and orchestra, which are regarded as symptomatic musical emblems of a combination of stylistic trends: the departing avant-garde and the approaching neo-romantic. In this way, they determine the caesuras of the qualitative transformations in Penderecki's style.

It must be noted that, initially, the paradigm of the new expression functioned in direct opposition to the avant-garde anti-art. The composers attempted to stress the romantic elements and radically turn away from the avant-garde language towards a wider audience. With time, the radicalism faded away and the composer intends to discover, i.e. "create the material in such relations that would allow the possibilities of music unknown to us so far to be revealed" (Schaeffer 1976: 12).

The compositions by Zygmunt Krauze, created at the end of the 1970s, are characterised by return to the past, deep emotionalism and variable expression. A work worth noting is Adieu, a 2001 piece written in the form of a capriccio for upright piano and orchestra. The innovative use of traditional instruments was dictated by the sound values that Krauze wished to obtain in order to present a climate of nostalgic tunes to the listener.

The trend will also be exemplified by works, uncomplicated and closed in form, which use the new media as a source of music and, at the same time, emphasise the melodic pattern characterised by deep emotionalism.

For instance, intermediality is present in the electroacoustic works by Andrzej Dobrowolski, created after 1975. A good example is Musik für Tonband und Bassklarinette from 1980, which combined sounds from traditional instruments and electronically generated

\footnotetext{
${ }^{3}$ Terminology following Mieczysław Tomaszewski.
} 
sound material, where the dependencies between the bass clarinet part and the recording tape part resemble the relations that can be observed in the case of a "classic" model of a solo concerto. The electronic composition by Dobrowolski Passacaglia für TX for tape, in turn, was created in two versions in the years 1988-1989. It was the first piece in which the composer made use of advanced, in those days, digital and computer technology. The title refers to the Yamaha TX digital synthesizer, which was employed for sound emission, and to the Baroque form. The Baroque passacaglia was presented according to the composer's own ideas by means of the "new" media.

Another instance of intermediality in a broad sense is Lidia Zielińska's piece from 2007 entitled Conrad's Seven Isles for electronic sound and 10 amplified instruments. Inspired by Joseph Conrad's Freya of the Seven Isles, the work places emphasis on making the listener sensitive to new qualities of sound.

What is worth quoting at this point is Krzysztof Knittel's recycling theory, which he has already used since the end of the $20^{\text {th }}$ century but did not formulate until 2011 (Barculewski 2012: 271). In Krzysztof Barculewki's words "recycling consists of the fact that in new pieces the composer uses in extenso or mutatis mutandis the material from works completed in the more or less distant past" (2012: 272). For the first time, Knittel used earlier material in 1994 in Sonata da camera No. 1 for trumpet and synthesizers. Similar to Dobrowolski, the composition is meant for two different media (a traditional instrument and electronics) which refer at the same time to tradition as regards the structure of the form. In 1997, in Doricos (seven miniatures for a string quartet and tape) Knittel presents the listener with a synthesis of musical matter and extra-artistic reality, i.e. a string quartet and the sounds of prison life recorded on tape along with Zbigniew Herbert's poem What Mr Cogito Thinks About Hell.

The hybrid nature may thus constitute one of the foundations of the intermedial concepts of art, which equals an explicit transgression of the avant-garde narration.

A systematic specification of the emblems of this artistic current is not an easy task since numerous works exhibit these correlations.

The compositions listed above are only examples that seem to meet the conditions of being representative of trans-avant-garde. Determination of a greater number of works which exhibit, in various degrees, the features of the described paradigm will be possible after conducting a multidimensional analysis and interpretation of compositions created after 1975. Both the features of "musical" trans-avant-garde and the suggested composition fitting this trend are purely postulatory in character and require additional interdisciplinary research to be conducted. Referring to Oliva's words quoted at the beginning of this paper, one may state that avant-garde has returned in a new "incarnation": in a version which gives sense and content to the work of art. 


\section{References}

Baculewski, K. 2012. Współczesność 1975-2000. Historia muzyki polskiej pod redakcja Stefana Sutkowskiego, Vol VII, Part 2. [E-book]. Warszawa: Narodowe Centrum Kultury.

Chłopecki, A. 2008. Mykietyna budowanie świata. Gazeta Wyborcza, 156: 26.

Dahlhaus, C. 1982. O pieśniach Karola Szymanowskiego do słów Richarda Dehmela. Zu Karol Szymanowskis Dehmel-Liedern. Res Facta, 9: 62-78.

Dziamski, G. 1995. Awangarda po awangardzie: Od neoawangardy do postmodernizmu. Poznań: Wydawnictwo Humaniora.

Dziamski, G. 2002. Spoglądając na sztukę minionego wieku. Estetyka i Krytyka, 2(3): 1-19.

Gołąb, M. 2003. Spór o granice poznania dzieła muzycznego. Wrocław: Fundacja na Rzecz Nauki Polskiej.

Gołąb, M. 2011. Muzyczna moderna w XX wieku: Między kontynuacja, nowościa, a zmiana fonosystemu. Wrocław: Wydawnictwo Uniwersytetu Wrocławskiego.

Jarzębska, A. 2004. Spór o piękno muzyki: Wprowadzenie do kultury muzycznej XX wieku. Wrocław: Wydawnictwo Uniwersytetu Wrocławskiego.

Morawski, S. 2007. Awangarda artystyczna (o dwóch formacjach XX wieku). In: S. Morawski, ed. Wybór pism estetycznych. Klasycy estetyki polskiej: 196-223. Kraków: Wydawnictwo Universitas.

Morawski, S., ed. 2007. Wybór pism estetycznych. Klasycy estetyki polskiej. Kraków: Wydawnictwo Universitas.

Nycz, R. 2013. Język modernizmu. Prolegomena historycznoliterackie. Toruń: Wydawnictwo Uniwersytetu Mikołaja Kopernika.

Oliva, A. B. 1979. The Italian Transavantgarde. Flash Art, 92-93: 17-20.

Oliva, A. B. 1980. The Italian Trans-avantgarde, Milan: Politi Editore.

Oliva, A. B. 1982. Trans-avantgarde international, Milan: Politi Editore.

Oliva, A. B. 2012. Krytyk musi być prorokiem. O. Święcicka, interviewer. Art \& Business, 2012(7-8): 115-118. Source:

http://oswiecicka.files.wordpress.com/2013/01/07_rozmowa_oliva.pdf, 19.09.2014.

Paja-Stach, J. 2007. Kompozytorzy polscy wobec idei modernistycznych i postmodernistycznych. A. Jarzębska, J. Paja-Stach, red. Idee modernizmu i postmodernizmu w poetyce kompozytorskiej i refleksji o muzyce: 55-73. Kraków: Musica Iagellonica.

Polony, L. 1991. Polski ksztalt sporu o istotę muzyki, Kraków: Wydawnictwo Akademii Muzycznej.

Rutkowska, A. 2005. Postmodernizm. In: M. Podhajski, ed. Kompozytorzy polscy 1918-2000, Vol. I, Eseje: 283-295. Gdańsk-Warszawa: Wydawnictwo Akademii Muzycznej w Gdańsku.

Schaeffer, B. 1976. Wstęp do kompozycji. Kraków: Polskie Wydawnictwo Muzyczne.

Skowron, Z. 1989. Teoria i estetyka awangardy muzycznej drugiej połowy XX wieku. Warszawa: Wydawnictwo Uniwersytetu Warszawskiego. 
Szwajgier, K. 2014. Summary of professional accomplishments referring to a one subject series of publications Od sonoryzmu do interfejsu. Muzyka polska w obliczu zmiany paradygmatów, presented for the habilitation procedure.

Tomaszewski, M. 2005. O muzyce polskiej w perspektywie intertekstualnej. Studia i szkice. Kraków: Wydawnictwo Akademii Muzycznej.

Wasilewska-Chmura, M. 2011. Przestrzeń intermedialna literatury i muzyki. Muzyka jako model $i$ tworzywo w szwedzkiej poezji późnego modernizmu i neoawangardy. Kraków: Wydawnictwo Uniwersytetu Jagiellońskiego.

Wilkoszewska, K. 2008. Wariacje na postmodernizm. Kraków: Wydawnictwo Universitas.

Woźna-Stankiewicz, M. 2007. Postawy artystyczne w XX wieku i problem tradycji w autorefleksji Bairda, Kilara i Meyera. In A. Jarzębska \& J. Paja-Stach, ed. Idee modernizmu i postmodernizmu w poetyce kompozytorskiej i refleksji o muzyce: 75-99. Kraków: Musica Iagellonica.

Virilio, P. 1991. Art and Philosophy. Interview. Milan: Giancarlo Politi Editore. 